Review Article

\title{
Understanding Diabetic Retinopathy in Ayurvedic Parlance - A Review Article
}

\author{
Rashmi PV', Naveen BS ${ }^{2}$, Vivek $]^{3}$, Ajoy Viswam ${ }^{4}$, Krishnan Namboodiri $^{5}$ \\ ${ }^{1} 2^{\text {nd }}$ Year, PG Scholar, ${ }^{2}$ Professor \& HoD, ${ }^{3}$ Associate Professor, ${ }^{4,5}$ Assistant Professor, Department of Shalakya Tantra, Sri Sri \\ Ayurvedic College and Research Hospital, Karnataka, India.
}

DOI: https://doi.org/10.24321/2394.6547.202003

\section{I $\quad \mathbf{N} \quad \mathbf{F} \quad \mathbf{O}$}

\section{Corresponding Author:}

Rashmi PV, Department of Shalakya Tantra, Sri Sri Ayurvedic College and Research Hospital, Karnataka, India.

E-mail Id:

dr.rashmipv@gmail.com

Orcid Id:

https://orcid.org/0000-0002-2986-0595

How to cite this article:

Rashmi PV, Naveen BS, Vivek J, Viswam A, Namboodiri K. Understanding Diabetic Retinopathy in Ayurvedic Parlance - A Review Article. J Adv Res Ayur Yoga Unani Sidd Homeo 2020; 7(1\&2): 12-15.

Date of Submission: 2020-04-29

Date of Acceptance: 2020-06-23

\section{$\begin{array}{llllllll}\mathbf{A} & \mathbf{B} & \mathbf{S} & \mathbf{T} & \mathbf{R} & \mathbf{A} & \mathbf{C} & \mathbf{T}\end{array}$}

According to $\mathrm{WHO} 60 \%$ of factors related to individual health and quality of life are mutually related to lifestyle. Over $61 \%$ of all deaths in India are due to lifestyle or Non Communicable Diseases. Diabetes and diabetic retinopathy have been emerging as an important non communicable disease affecting eye. Prameha leading to dristigata roga based on the basic principles of Ayurveda and effect on netrapatalas leading progressively to timira, kacha, linganasha thereupon is analysed. Charaka Samhita, Sushrutha Samhitha, Ashtanga Hridaya and various research articles and contemporary science books of the concerned subject are referred. Management of the condition involves Nidana Parivarjana and the treatments as per Ayurvedic classics help in Samprapti Vighatana thereby giving relief to the patient. Proper and timely treatment by Ayurveda helps in reversing damage to the eyes and better management of the condition.

Keywords: Diabetic Retinopathy, Ayurveda, Prameha, Timira, Literary Review

\section{Introduction}

According to $\mathrm{WHO}, 60 \%$ of factors related to individual health and quality of life are mutually related to lifestyle. ${ }^{1}$ Lifestyle is a major factor thought to influence susceptibility to many diseases including eye. Habits like sedentary routine, smoking, drinking alcohol, poor diet leads to lifestyle disorders. Over $61 \%$ of all deaths in India are due to lifestyle disorders. ${ }^{2}$ Diabetes being one among the major lifestyle related disease is a complex metabolic disorder wherein persistent hyperglycaemia and glucose intolerance is seen due to the pancreas not producing enough insulin hormone or ineffective use of insulin by the body. Type 2 diabetes is the most common type found, accounting for approximately up to $95 \%$ of diabetes in developing countries. Hyperglycaemia in Diabetes overtime impacts systems of the body especially nerves and blood vessels.
Diabetes and Diabetic Retinopathy (DR) have been emerging as an important non communicable disease affecting eye. DR is a complication of Diabetes mellitus wherein the micro vascular structure of the eyes gets affected. Prevention and management of chronic conditions is an important part of our overall health, especially when it comes to our eyes. The World Health Organisation estimated the global prevalence of diabetes among adults over 18yrs of age as $8.5 \%$ in 2014.Indian health ministry's first national diabetes and diabetic retinopathy survey (2015-19) has revealed that the prevalence of DR is $16.9 \%$ while the prevalence of sight threatening DR is $3.6 \%$. Mild retinopathy was the most common with prevalence of $11.8 \% .^{3}$

\section{Diabetic Retinopathy ${ }^{4}$}

$D R$, one of the leading causes of blindness around the world being a progressive disorder of the eye that occurs 
in the following 3 stages:

1. No apparent DR

2. Non-Proliferative (NPDR)

3. Proliferative (PDR): Neovascularisation of the disc, Neovascularisation of the retina

NPDR is further sub-divided into:

- $\quad$ Mild (At least one micro aneurysm)

- Moderate [Extensive intra-retinal haemorrhages and/ or micro aneurysms and/or cotton wool spots, venous beading or intra-retinal micro vascular abnormalities (IRMA) definitely present, but not as severe as severe NPDR]

- Severe (Intra-retinal haemorrhages in four quadrants, Venous beading in two quadrants, Severe IRMA in one quadrant)

\section{Materials and Methods}

All the relevant Ayurvedic books like Charaka Samhita, Sushrutha Samhitha, Ashtanga Hridaya and various research articles, websites and contemporary science books of the concerned subject are referred and critically analysed.

\section{Result \& Discussion}

Eye has been given utmost importance in Ayurveda as it is one among the twelve praana considered classically. ${ }^{5}$ Pitta has one of its natural seats in eyes helping in carrying out its prakrutha karma of darshana ${ }^{6}$ because of Agni mahabhoota predominance. According to Ayurveda classics main doshas like Prana vayu, Vyana vayu, Chakshurvaisheshika Alochaka pitta, ${ }^{7}$ Tarpaka kapha are involved in the maintenance of physiological functions of eyes. ${ }^{8,9,10}$ Eyes are especially vulnerable to vitiated kapha dosha ${ }^{11}$ and Prameha is basically a tridoshaja vyadhi with kaphadosha predominance, wherein the dravaguna of kapha is in increased state due to nidana sevana like aasyasukha, swapnasukha, dadhi etc., ${ }^{12}$ which are achakshushya as well and they inturn vitiate mamsa and shareeraja kleda thus contributing in the pathogenesis of the disease enhancing the vulnerability of eye disease as well in the process, wherever khavaigunya is found in the sthana of chakhurindriya. Rogotpatti hetu according to acharya Vagbhata includes agnimandhya because of which saama condition manifests wherein srotorodha can be seen ${ }^{13}$ like atipravritti type seen in prameha due to medovaha srotodushti exhibiting bahumutrata (excessive passage of urine) lakshana. Involvement of vital organs like eye in prameha samprapti has been mentioned by acharya Charaka as netra upalepa ${ }^{14}$ wherein upalepa is the prakupita kapha karma. ${ }^{15}$ Since srotas is the inner transport system of the body which provide platform for activities of other important bio-factors like three doshas, the seven dhatus, the ojas, the agni etc., ${ }^{16}$ so its affliction hampers the normal physiology of the body thus contributing in the pathogenesis of the disease like in Pramehajanya netra roga which occurs as an upadrava of Prameha, wherein ksheena ojus, vitiated dushyas and doshas move in the siras in urdhvajatru which upon reaching netra manifest netra roga lakshanas by affecting the normal physiology of the eye. ${ }^{17}$ As Netrapatalas and some dhatus have ashrayaashrayibhaava sambandha, ${ }^{18}$ patalas gets afflicted as such with the vitiated doshas in untreated/chronic/poorly managed Prameha roga accordingly as dhatvagnimandhya leads to poor nourishment of the respective dhatus and resultant dhatukshaya along with increased malaroopi pitta, kapha carried in rakta affects drustimandala thereby manifesting lakshanas of Timira, Kacha and Linganasha in stages with the affliction of prathama, dvitiya, trithiya, chathurtha patalas with the chronicity of the disorder.

Fundoscopic findings of DR like hard exudates, microaneurysms, intraretinal haemorrhages, cotton wool spots, neovascularisation can be understood in Ayurvedic parlance as follows :

Hard exudates consists of lipid residues of serous leakage that settle in outer retinal layers indicating a leakage from the circulation at a level which probably requires a degree of structural damage to retinal vascular endothelium this can be understood by knowing the prakupita kapha karma of sneha katiny $a^{15}$ occuring due to damage of raktadharakala which is basically present in mamsa and siras which has similarities with the endothelial lining of blood vessels associated with vyana vata vikruti.

Micro aneurysms usually temporal to the fovea seen in mild NPDR are the earliest clinically visible changes seen in the retina wherein local expansion of the capillaries due to disruption of the internal elastic lamina of the blood vessel leading to vascular endothelial dysfunction which can be understood by understanding siraasaithilya occuring due to dhatukshaya in Prameha as a result of excessive apatarpana associated with Sira-Granthi type of srotodusti in raktavaha srotas thereby causing dristikshaya.

Intra-retinal haemorrhages appear as a result of ruptured micro aneurysms, capillaries and venules of the retinal vasculature; this can be understood with vimargagamana and atipravritti of vitiated vyana vayu, praana vayu, carried in the rakta dhatu whose vitiation causes malaroopi pittavriddi in the abhyantara mukha srotas i.e., raktavaha srotas caused as a result of causes like excess snigdha, vidahi aahara, aatapa sevana etc, thereby affecting the raktadharakala by the ushna guna of vitiated pitta and pressure increase due to increased doshas and dhatu as a result, presents with urdhwaga raktapitta lakshanas which occurs in association with vitiated kapha dosha as bleeding in netra affecting the dristi which is one of the main seat of pitta.

Cotton wool spots are seen as localised white-yellowish 
fluffy areas of discolouration and are a consequence of capillary occlusion in the nerve fibre layer of retina indicating infarction at the site which can be understood due to prakupitha kapha and medas which vitiates due to common causes like avyaayama (lack of exercise), divaswapna (daytime sleep), medhyaanam atibhakshanaath (fatty food over intake), vaarunya atisevana (intake of excess alcohol) leading to medovahasrotodust ${ }^{19}$, sleshmavahasrotodusti causing sanga in raktavahasrotas.

Neovascularisation seen in case of PDR wherein new blood vessels proliferate from pre-existing retinal blood vessels stimulated by retinal ischemia in order to revascularise the hypoxic areas can be understood as Vata being pravartaka of chesta ${ }^{20}$ the cell division occuring in the proliferation of blood vessels can be attributed to one of its function, also due to Praana vayu aavarana of Vyanavata, ${ }^{21}$ associated with vitiated kapha and medas causing atipravritti type of srotodusti in raktavahasrotas leads to vaishamya of raktavahasiras thereby it affects roopagrahana.

\section{Treatment}

Although retinal laser photocoagulation, anti vascular endothelial growth factor injections and vitrectomy are the line of treatments in the contemporary science for diabetic retinopathy they do not address the fundamental disease processes associated with the occurrence of retinopathy and also they are not without any side effects. In Ayurveda, since Prameha is one among eight mahagadas, because of its deep rooted nature and possibility of development of complications, it needs to be managed through multi-angle approach starting from stressing on Nidana Parivarjana i.e., avoidance of causative factors which in the case of Pramehajanya netra roga involves avoidance of nidana factors causing Prameha, along with Samprapti Vighatana chikitsa considering the deha prakruthi, desha, bala, kala, vyadhi avastha etc., creating niraama avastha, Shodhana therapy like Virechana, Nasya, Basti like Chakshusya Basti which has Yashtimadhu as a main chakshushya ingredient, Shamana therapy which includes mitigation of vitiated doshas with drugs accordingly like having Chakshushya, kaphahara, medohara gunas like Punarnavastaka kashaya, Jeevanthyadi ghrita, Mahatriphaladi ghrita, Saptamrita loha, Durvadi ghrita, Mahavasakadi kashaya for sthambana in haemorrhagic condition. Sthanika netra chikitsa with Netra Kriyakalpas like Tarpana, Putapaka, Seka, Anjana, Aschyotana, Vidalaka, using drugs like triphala, lodhra, yashtimadhu, loha, madhu, etc according to the stage of the disease. Murdhni tailas especially mentioned in classics like Shirobasti, Shirodhaara etc helps in indriya tarpana and prasaadana which can be practiced using medications accordingly.

\section{Conclusion}

Effect of Prameha on eye has been described in Ayurvedic classics of the Samhitha period dating back to $6^{\text {th }}-7^{\text {th }}$ century $\mathrm{BC}$ whereas Diabetic retinopathy came up to be diagnosed in contemporary science only from 1855 and it can be understood in the present era with multi-dimensional approach involving concepts of Tridoshas, Dushyas, Srotas, Kala, Agni, Aavarana, Aama, etc . Having regular comprehensive eye examinations can detect problems long before symptoms show up and should be an important part of our regular preventive health routine. Strong methods to control the use of and exposure to tobacco, coupled with promotion of healthy lifestyles, should be an integral part of any national program. Vaidyas using their yukti combined with the principles of shastra can develop simple easy to follow treatment modalities, and contribute to the building of healthy independent society which inturn helps in the economic growth of the country by reducing the morbidity and dependence of the population by strengthening the human resource of the nation.

\section{Conflicts of Interest: None \\ References}

1. Healthy Living : What Is a Healthy Lifestyle? World Health Organization. World Health Organization, January 1, 1999. https://apps.who.int/iris/handle/ 10665/108180?show=full.

2. Lifestyle Disorder. Lifestyle Disorder | National Health Portal of India. Accessed May 1, 2020. https://www. nhp.gov.in/lifestyle-disorder_mtl.

3. Sharma NC. Government Survey Found $11.8 \%$ Prevalence of Diabetes in India. Livemint, October 10, 2019. https://www.livemint.com/science/health/ government-survey-found-11-8-prevalence-ofdiabetes-in-india-11570702665713.html.

4. Steele, Chris. Diabetes and the Eye. 2008th ed. Edinburgh: Elsevier Limited, n.d.

5. Acharya S. Sushrutha Samhitha with Nibandha Sangraha Commentary of Dalhanacharya. 2014th ed. Vol. Shareerasthana. Varanasi: Chaukhamba Krishnadas academy, 2014.

6. Acharya, Agnivesha. Charaka Samhitha . $2008^{\text {th }}$ ed. Vol. Suthrasthana. Chaukhamba Surabharathi prakashan, n.d.

7. Srinivasa R. Samhitha B. $1^{\text {st }}$ ed. Vol. Shareerasthana. Chaukhamba Krishnadas academy, 2010.

8. Acharya, Vagbhata. Ashtanga Hrudaya with Commentaries of Arunadatta and Hemadri, Suthrasthana. 2002 ${ }^{\text {nd }}$ ed. Chaukhamba surabharathi prakashana, n.d.

9. Agnivesha A. Charaka Samhitha Chikitsasthana. 2008 ed. Chaukhamba Surabharathi prakashan, n.d.

10. Acharya, Sushrutha. Sushrutha Samhitha with Nibandha Sangraha Commentary of Dalhanacharya. $2014^{\text {th }}$ ed. 
Vol. Suthrasthana. Varanasi: Chaukhamba Krishnadas academy, 2014.

11. Acharya, Agnivesha. CharakaSamhitha. $2008^{\text {th }}$ ed. Vol. Suthrasthana. Chaukhamba Surabharathi prakashan, n.d.

12. Acharya, Agnivesha. CharakaSamhitha. $2008^{\text {th }}$ ed. Vol.Chikitsasthana. Chaukhamba Surabharathi prakashan,n.d.

13. Acharya, Vagbhata. Ashtanga Hrudaya with Commentaries of Arunadatta and Hemadri, Suthrasthana. $2002^{\text {nd }}$ ed. Chaukhamba surabharathi prakashana, n.d.

14. Acharya, Agnivesha. CharakaSamhitha. $2008^{\text {th }}$ ed. Vol. Nidanasthana. Chaukhamba Surabharathi prakashan, n.d.

15. Acharya,Vagbhata. Ashtanga Hrudaya with Commentaries of Arunadatta and Hemadri, Suthrasthana. $2002^{\text {nd }}$ ed. Chaukhamba surabharathi prakashana, n.d.

16. Chandrakant, Vd. Khendkar Jayashree and Pawar Jatved Janardhanrao. Physiological and Clinical Significance of Srotas. International Journal of Health Sciences and Research 6, no. 9 (September 2016).

17. Acharya, Sushrutha. Sushrutha Samhitha with Nibandha Sangraha Commentary of Dalhanacharya. 2014 ${ }^{\text {th }}$ ed. Vol.Uttarasthana. Varanasi: Chaukhamba Krishnadas academy, 2014.

18. Acharya, Sushrutha. Sushrutha Samhitha with Nibandha Sangraha Commentary of Dalhanacharya. $2014^{\text {th }}$ ed. Vol.Uttarasthana. Varanasi:Chaukhamba Krishnadas academy, 2014.

19. Acharya, Agnivesha. Charaka Samhitha Chikitsasthana. $2008^{\text {th }}$ ed. Chaukhamba Surabharathi prakashan, n.d.

20. Gowda, Shivkumar. Ayurvedeeya Shareera Kriya Vijnana. 5th ed. Rohtak: Nath Pusthaka bhandara, n.d.

21. Sahoo, Prashanth Kumar, and Shamsa Fiaz. Conceptual Analysis of Diabetic Retinopathy in Ayurveda. Journal of Ayurveda and Integrative Medicine 2017. 